\title{
Differentiation of Seiridium species associated with virulent cankers on cypress in the Mediterranean region by PCR-SSCP
}

\author{
S. Moricca ${ }^{a \star}+$, I. Børja ${ }^{b}$, G. G. Vendramin ${ }^{c}$ and P. Raddi ${ }^{\mathrm{a}}$ \\ ${ }^{a}$ CNR, Istituto per la Patologia degli Alberi Forestali, Piazzale delle Cascine 28, I-50144 Firenze, Italy; ${ }^{b}$ Norwegian Forest Research \\ Institute, Høgskoleveien 12, N-1432 Ås, Norway; and ${ }^{\circ} \mathrm{CNR}$, Istituto di Miglioramento Genetico delle Piante Forestali, \\ via Atto Vannucci 16, I-50134 Firenze, Italy
}

A rapid and sensitive method was developed to discriminate between Seiridium cardinale and Seiridium cupressi, the fungi causing severe cankers on common cypress in the Mediterranean area. The method amplified sequence variants in the ITS2 region of ribosomal DNA using the polymerase chain reaction (PCR), followed by polyacrylamide gel electrophoresis, to reveal single-strand conformation polymorphism (SSCP) between the two species. The greatest separation pattern was obtained with a gel matrix containing $7-10 \%$ formamide and $3-5 \%$ glycerol under optimized running conditions, which were found to be $30-40 \mathrm{~V}$ at $4-5^{\circ} \mathrm{C}$ for $4-8 \mathrm{~h}$. Sequence homology among isolates within each of the two species caused no mobility shifts, with all isolates displaying the same migration pattern. A few base differences between $S$. cardinale and $S$. cupressi caused markedly different migration patterns, allowing differentiation of the two pathogens. Differences between these fungi at the genetic level are consistent with known data on morphological, physiological and pathogenic characteristics. SSCP analysis constitutes a rapid and easy-to-perform method by which to recognize and distinguish closely related organisms, and has considerable potential for use in diagnosis and taxonomy.

Keywords: cypress canker, ITS2 sequence variation, polymerase chain reaction-single strand conformation polymorphism (PCR-SSCP), Seiridium cardinale, Seiridium cupressi

\section{Introduction}

The common cypress (Cupressus sempervirens) is severely under threat from the highly destructive fungal parasite Seiridium cardinale (Graniti, 1993). This mitosporic coelomycete, originating from California, USA on native trees of the family Cupressaceae (Wagener, 1939), was reported in Europe around the middle of the 20th century (Barthelet \& Vinot, 1944; Grasso, 1951). The presence of highly susceptible hosts and climatic conditions favourable for reproduction of the pathogen facilitated its establishment and spread in the Mediterranean area, where it has caused destructive and recurrent epidemics of canker that have decimated ornamental trees, windbreaks, natural stands and cypress plantations (Solel et al., 1983; Graniti, 1986; Raddi et al., 1987; Luisi, 1990).

Sanitary measures such as fungicide treatments or the

\footnotetext{
"To whom correspondence should be addressed. †E-mail: tmoricca@ipaf.fi.cnr.it Accepted 9 June 2000.
}

removal and destruction of infected branches and severely infected or dead trees have not resulted in a significant decrease in the current epidemics of cypress canker, the most effective control strategy having been the adoption of cypress-breeding programmes for canker resistance. Four cypress clones have been patented for resistance to cypress canker and are now commercially available (Panconesi \& Raddi, 1990, 1991).

A congeneric fungus, identified as Seiridium cupressi, is also present in the Mediterranean basin. First reported from Kenya in the 1940s, where it caused heavy losses on Monterey cypress (Cupressus macrocarpa; Wimbush, 1944; Nattrass, 1945), it was also recently reported as the cause of a canker disease on the Greek island of Kos in the Aegean (Xenopoulos, 1987). Data on the severity of cankers caused by the disease in the hottest months of the year suggest that it is imperative to avoid any further spread of the pathogen in this area. In particular, comparative studies on the pathogenicity of $S$. cardinale and $S$. cupressi revealed that the latter is capable of causing persistent infections in the warm season, during which the cankers it causes develop more quickly than those caused by $S$. cardinale 
(Xenopoulos, 1991). Furthermore, S. cupressi is most active precisely during the period when $S$. cardinale becomes less active. Their pathogenic activity indicates that if these two pathogens were to act jointly on a single tree, as has already been reported from southern Africa (Viljoen et al., 1993), they could cause very severe damage.

The resistance of cypress to attacks by $S$. cardinale has been reported to be a nonspecific process, essentially based on the ability of the tree to compartmentalize wounds, and on the invulnerability of the reaction tissues (Ponchet \& Andreoli, 1990). The introduction of $S$. cupressi into currently uncontaminated areas and the combined action of these two pathogens could overcome the host defence reaction and be lethal for cypress, frustrating previous and ongoing efforts toward the selection and breeding of cypress genotypes and clones for resistance to $S$. cardinale (Raddi et al., 1990).

The threat of the spread of $S$. cupressi in the Mediterranean must be urgently addressed not only on account of the virulence of the pathogen, which appears to be linked to its ability to produce highly toxic metabolites (Sparapano et al., 1994), but also because of its epidemiological significance, chiefly on account of the risk of wind dispersal of ascospores produced by the teleomorph, Lepteutypa cupressi (A. Graniti, personal communication).

Traditional methods for identifying these fungi are based primarily on cultural and morphological characteristics including growth rate; growth/temperature relations; shape, colour and texture of colonies; density of aerial hyphae; size and morphology of conidia; presence/absence of conidial appendages; and length and morphology of basal and apical conidial appendages. Various studies have shown problems with this approach because of the inconstancy and variability of certain characters such as colour, shape, and the curvature of the conidia and conidial appendages (Nattrass et al., 1963; Swart, 1973; Sutton, 1980; Boesewinkel, 1983; Graniti, 1986; Chou, 1989; Nag Raj, 1994).

An alternative approach is to use a molecular technique such as polymerase chain reaction-single strand conformation polymorphism (PCR-SSCP) analysis, with the aim of developing a sensitive and rapid assay that can be employed in routine diagnosis, in place of both ineffective traditional techniques and time-consuming post-PCR processing methods.

The variable internal transcribed spacer 2 (ITS2) region of the ribosomal DNA was selected as a target. To explore the extent of sequence variation existing between the two fungi, and to clarify the composition and distribution of the sequence variants (which, in the SSCP analysis, would presumably have affected intrastrand interaction and altered migration during electrophoresis), this region from one selected, authenticated isolate per species was subjected to prior PCR amplification and sequencing. In addition, this method was compared with postamplification restriction fragment length polymorphism (RFLP) analysis.

\section{Materials and methods}

\section{Growth of fungal isolates}

A total of 28 isolates found on various hosts of the family Cupressaceae, were used (Table 1). Isolates of $S$. cardinale came from Mediterranean countries (France, Greece, Italy, Portugal, Spain and Turkey), where the disease incidence is currently higher than elsewhere, and originated from geographically distant areas that were fairly representative of the major foci of the disease. To date, $S$. cupressi has been reported only on the small island of Kos in Greece. Two different test isolates were used from this location, one grey and the other rosecoloured in culture (Xenopoulos, 1991). The remaining $S$. cupressi isolates were of diverse geographic origin, and represented the existing type-cultures of this species.

Single-conidium stock cultures were grown using liquid stationary culture in Norkrans medium (Norkrans, 1963) on 9-cm-diameter plastic Petri dishes at a temperature of $24^{\circ} \mathrm{C}$. After $1-2$ weeks of culturing a dense mycelial mat had covered the surface of the medium. Approximately 15-20 g fresh mycelium was harvested by vacuum filtration through Miracloth (Calbiochem, San Diego, CA, USA). Fungal mycelium was then washed with double-distilled, autoclaved water, dried on absorbent paper, weighed, frozen using liquid $\mathrm{N}_{2}$, and lyophilized.

\section{DNA preparation}

Lyophilized mycelium was ground under liquid $\mathrm{N}_{2}$ to a fine powder. Genomic DNA was extracted using a modified version of the Raeder \& Broda (1985) and Lee $\&$ Taylor (1990) protocols. Approximately $30 \mathrm{mg}$ mycelial powder was transferred to a screw-top $1.5 \mathrm{~mL}$ Eppendorf tube and suspended in $750 \mu \mathrm{L}$ extraction buffer (200 mm Tris- $\mathrm{HCl} \mathrm{pH} \mathrm{8.5,} 250 \mathrm{~mm}$ $\mathrm{NaCl}, 25 \mathrm{~mm}$ EDTA, 0.5\% SDS). The suspension was incubated at $65^{\circ} \mathrm{C}$ for $1 \mathrm{~h}$ and $600 \mu \mathrm{L}$ of $(1: 1)$ phenol : chloroform was added. After mixing at $20^{\circ} \mathrm{C}$ for $15 \mathrm{~min}$ the suspension was centrifuged for $30 \mathrm{~min}$ at $13000 \mathrm{~g}$ (Beckman L8-M ultracentrifuge, Fullerton, CA, USA), and the supernatant removed to another tube where it was incubated for $15 \mathrm{~min}$ at $37^{\circ} \mathrm{C}$ in $100 \mu \mathrm{L}$ RNase A solution $\left(20 \mathrm{mg} \mathrm{mL}^{-1}\right)$. This solution was again extracted with phenol : chloroform as described above, and the resulting supernatant re-extracted using chloroform : isoamyl alcohol $(24: 1,600 \mu \mathrm{L})$. After centrifugation at $13000 \mathrm{~g}$ for a further $10 \mathrm{~min}$, the supernatant was removed and DNA precipitated by the addition of $0 \cdot 1$ vol $3 \mathrm{~m}$ sodium acetate and 0.6 vol $-20^{\circ} \mathrm{C}$ absolute ethanol. The DNA was pelleted by centrifugation at $13000 \mathrm{~g}$ for $15 \mathrm{~min}$ at $4^{\circ} \mathrm{C}$. DNA pellets were washed in $80 \%$ ice-cold ethanol, centrifuged at $10000 \mathrm{~g}$ at $4^{\circ} \mathrm{C}$ for $5 \mathrm{~min}$ to remove salts, and vacuum-dried. The DNA pellets were 
Table 1 Seiridium isolates used in polymerase chain reaction-single strand conformation polymorphism assays and their sources

\begin{tabular}{|c|c|c|c|c|c|}
\hline Fungus & Code & Original host & Location & Country & Supplier \\
\hline \multirow[t]{18}{*}{ Seiridium cardinale } & $2 G^{a}$ & Cupressus goveniana & Var & France & C. Andreoli \\
\hline & $1 \mathrm{Ccl}^{\mathrm{a}}$ & Cupressocyparis leylandii & Drôme & “ & " \\
\hline & Fclus69 ${ }^{b}$ & Cupressus Iusitanica & Antibes & “ & “ \\
\hline & $10 S^{a}$ & Cupressus macrocarpa & Île St-Honoret & " & “ \\
\hline & $30 S^{a}$ & Cupressus dupreziana & Gard & " & “ \\
\hline & $\mathrm{Kar}^{\mathrm{b}}$ & Cupressus sempervirens & Karistos & Greece & S. G. Xenopoulos \\
\hline & Mouz $^{\mathrm{b}}$ & " & Mouzaki & “ & “ \\
\hline & Sam $^{b}$ & “ & Samos & " & “ \\
\hline & ATCC 38654 & “ & Monte Morello, Florence & Italy & A. Panconesi \\
\hline & $\mathrm{Scr}^{\mathrm{b}}$ & Cupressus macrocarpa & Roselle, Grosseto & “ & " \\
\hline & $\operatorname{Scj}^{\mathrm{b}}$ & Juniperus communis & Capannuccia, Florence & " & “ \\
\hline & Bsc $61^{b}$ & Cupressus sempervirens & Putignano, Bari & " & N. Luisi \\
\hline & $\mathrm{B} 21^{\mathrm{b}}$ & Juniperus communis & Bernalda, Matera & “ & L. Sparapano \\
\hline & $\mathrm{Fsc} 49^{\mathrm{b}}$ & Cupressus sempervirens & Lisbon & Portugal & M. F. Caetano \\
\hline & Scp $1^{\text {b }}$ & “ & Javira, Algarve & " & J. Pinto Gañhao \\
\hline & $\mathrm{Fsc} 2^{\mathrm{b}}$ & “ & Terragona & Spain & J. J. Tuset \\
\hline & $\mathrm{Fsc} 46^{\mathrm{b}}$ & “ & Diga & " & “ \\
\hline & $\mathrm{Fsc} 38^{\mathrm{b}}$ & “ & Mugla, Inisdibi & Turkey & P. Raddi \\
\hline \multirow[t]{10}{*}{ Seiridium cupressi } & Bsc55 $5^{b}$ & “ & Kos Island & Greece & S. G. Xenopoulos \\
\hline & $\mathrm{Kos}^{\mathrm{b}}$ & “ & Kos Island & " & " \\
\hline & ATCC 48158 & Cupressocyparis leylandii & - & New Zealand & H. J. Boesewinkel \\
\hline & CBS $319 \cdot 51$ & Cupressus sp. & - & Kenya & R. Ciferri \\
\hline & CBS $320 \cdot 51$ & “ & - & “ & “ \\
\hline & CBS224.55 & Cupressus macrocarpa & - & England & D. Rudd Jones \\
\hline & CBS225.55 & Cupressus forbesii & - & " & " \\
\hline & CBS226.55 & Cupressus macrocarpa & - & “ & “ \\
\hline & CBS227.55 & “ & - & “ & “ \\
\hline & BS228.55 & Juniperus procera & - & “ & “ \\
\hline
\end{tabular}

Abbreviations: ATCC, American Type Culture Collection; CBS, Centraalbureau voor Schimmelcultures

${ }^{\text {a } C u l t u r e ~ c o d e ~ a s s i g n e d ~ b y ~ t h e ~ s u p p l i e r . ~}$

${ }^{\mathrm{b}}$ Culture code assigned at the IPAF (Istituto per la Patologia degli Alberi Forestali, Florence, Italy).

-, Location unknown.

resuspended in $50 \mu \mathrm{L}$ TE buffer (Tris $\mathrm{HCl} 10 \mathrm{~mm}$, EDTA $1 \mathrm{~mm}, \mathrm{pH} 8$ ).

\section{PCR amplification}

The rDNA ITS2 region was amplified using the general primers ITS3 (5'-GCATCGATGAAGAACGCAGC-3') and ITS4 (5'-TCCTCCGCTTATTGATATGC-3'), which anneal to conserved portions of the $5.8 \mathrm{~S}$ and $26 \mathrm{~S}$ ribosomal genes of several fungal species (White et al., 1990). Stock DNA was quantified using a TKO 100 fluorometer (Hoefer Pharmacia Biotech, San Francisco, CA, USA) and diluted to $10 \mathrm{ng} \mu \mathrm{L}^{-1}$. Amplification was carried out in $25 \mu \mathrm{L}$ volumes containing $0.2 \mu \mathrm{M}$ of each primer; $2.5 \mu \mathrm{L} 10 \times$ Taq DNA polymerase buffer (10 mм Tris $\mathrm{HCl} \mathrm{pH} \mathrm{8.3,} 1.5 \mathrm{~mm} \mathrm{MgCl}_{2}, 50 \mathrm{~mm} \mathrm{KCl}$, $0 \cdot 1 \mathrm{mg}$ gelatin); $200 \mu \mathrm{m}$ each of dATP, dCTP, dGTP and dTTP; $10 \mathrm{ng}$ template DNA; 0.5 units Taq DNA polymerase (Pharmacia Biotech, Uppsala, Sweden). Incubation was performed in a GeneAmp PCR 9600 thermal cycler (Perkin Elmer Cetus, Applied Biosystem Division, Foster City, CA, USA) using the following cycle parameters: $94^{\circ} \mathrm{C}$ for $60 \mathrm{~s}, 50^{\circ} \mathrm{C}$ for $60 \mathrm{~s}$, and an extension step at $72^{\circ} \mathrm{C}$ for $120 \mathrm{~s}$ initially and increased by $1 \mathrm{~s}$ per cycle, using the maximum ramp time between each temperature. The total number of cycles was 35 , with an initial denaturation step of 2 min at $94^{\circ} \mathrm{C}$ and a final extension step of $8 \mathrm{~min}$ at $72^{\circ} \mathrm{C}$. A negative control with all reagents except DNA was included in all reactions. Results of amplification were checked by electrophoresis on $1 \%$ agarose gel (Pharmacia), stained with ethidium bromide, visualized under a UV transilluminator and photographed.

\section{Restriction enzyme digestions and mapping}

The amplification products were subjected to restriction enzyme analysis. All restriction enzymes were purchased from Bethesda Research Laboratories (Gaithersburg, MD, USA) and used in accordance with the supplier's instructions. Briefly, $10 \mu \mathrm{L}$ aliquots of amplified product, a restriction enzyme with its buffer, and water to make up volume were incubated at $37^{\circ} \mathrm{C}$ for $1-$ $2 \mathrm{~h}$ or overnight. Absence or presence and size of bands were scored for the restriction enzymes $A l u \mathrm{I}, D d e \mathrm{I}$, HaeIII, HhaI, Hinfl, MaeII, MspI, RsaI, Sau3AI and TaqI, and for the combinations HinfI/HaeIII, HhaI/ DdeI and MspI/AluI. Restriction fragments were separated on $2 \%$ agarose gel in $1 \times$ TBE buffer $(89 \mathrm{~mm}$ Tris-boric acid and $2 \mathrm{~mm}$ EDTA) with $0.5 \mu \mathrm{g} \mathrm{mL}$ 
ethidium bromide, visualized and photographed under UV light.

\section{DNA sequencing}

The PCR-amplified ITS2 region of two selected isolates, one of $S$. cardinale (Fclus69) and one of $S$. cupressi (Kos), was sequenced directly after isolation from lowmelting agarose gel. PCR products were purified using the Prep-A-Gene kit (BioRad, Richmond, CA, USA), and sequenced by the dideoxy method (Sanger et al., 1977) using a Sequenase 2.0 kit (USB, United States Biochemical Corporation, Cleveland, OH, USA). The two PCR primers ITS3 and ITS4 served as sequencing primers for both strands of the intergenic region (White et al., 1990). PCR products were radiolabelled with ${ }^{35} \mathrm{~S}$ following the supplier's instructions. Sequence reactions were run for approximately $3 \mathrm{~h}$ on $5 \%$ polyacrylamide wedge gels in a TBE buffer. Gels were fixed, vacuumdried and exposed to Kodak SB X-ray film for varying periods.

\section{SSCP analysis}

To denature the double strands prior to electrophoresis, $3 \mu \mathrm{L}$ aliquots of the PCR product were mixed with $10 \mu \mathrm{L}$ deionized formamide and $7 \mu \mathrm{L}$ loading buffer (50\% sucrose, $60 \mathrm{~mm}$ EDTA, 0.25\% bromophenol blue). The mixture was incubated for $3 \mathrm{~min}$ at $95^{\circ} \mathrm{C}$, then immediately cooled in an ice bath to avoid renaturation of the individual strands. Ten $\mu \mathrm{L}$ of the mixture was then loaded on $15 \times 15 \mathrm{~cm}$ vertical nondenaturing polyacrylamide gels (acrylamide : bisacrylamide $89: 1$ ) (Hoefer Pharmacia Biotech, San Francisco, CA, USA), in a $1 \times$ TBE buffer $(89 \mathrm{~mm}$ Tris-boric acid, $2 \mathrm{~mm}$ EDTA). To evaluate whether experimental conditions affected the pattern obtained, electrophoretic migration was tested at a number of temperatures (from $22^{\circ} \mathrm{C}$ to $4^{\circ} \mathrm{C}$ ), voltages $(20-100 \mathrm{~V}$ ) and gel running times (from $1.5 \mathrm{~h}$ to overnight). To find the optimal conditions for separation of single DNA strands, migration was also tested in gels containing varying amounts of formamide $(3-30 \%)$ and glycerol $(1-10 \%)$. The strands were visualized by silver staining (Bassam et al., 1991).

\section{Results}

\section{PCR amplification}

The DNA concentration of all extractions was determined using a DyNA Quant 200 (Hoefer) fluorometer and adjusted to $10 \mathrm{ng} \mu \mathrm{L}^{-1}$ for PCR amplification. All DNAs proved to be amplifiable under the PCR conditions employed. Migration of the resulting PCR products on $1 \%$ agarose gel revealed that amplification of the ITS2 region with the primers ITS3-4 produced a fragment of roughly $340 \mathrm{bp}$ in all isolates investigated. The amplified fragment included the entire ITS2 region, the two primer annealing sites, and a portion of the $5 \cdot 8 \mathrm{~S}$ and $26 \mathrm{~S}$ ribosomal genes (Fig. 1).

\section{Restriction data analysis}

RFLP analysis proved completely ineffective for discriminating between the two fungi. Most restriction endonucleases (HaeIII, HhaI, MaeII, MspI, RsaI and TaqI) failed to produce any band in the small ITS2 fragment. The RFLP patterns observed in S. cardinale digests did not differ from those observed in $S$. cupressi for the enzymes AluI, DdeI, HinfI and Sau3AI, with all isolates displaying identical restriction profiles (Fig. 2). The ITS2 region was therefore shown to be highly conserved for all isolates analysed.

\section{Sequencing the ITS2 region}

The sequence of the ITS2 region was determined in the amplification products of the two selected isolates of $S$. cardinale and $S$. cupressi. PCR products were found to vary between the species in both length and nucleotide sequence, while isolates within each species had identical sequences. Length was also constant within each species: the ITS2 region was $159 \mathrm{bp}$ long in samples of $S$. cardinale and 158 bp long in samples of $S$. cupressi. The $S$. cupressi sequence differed from the consensus $S$. cardinale sequence at three positions: 5, 84 and 158 , with loss of $A$ residues at position $5, \mathrm{G} \rightarrow \mathrm{C}$ transversions at position 84 , and $\mathrm{G} \rightarrow \mathrm{T}$ transversions at residue 158 (Fig. 2).

\section{Detection of DNA polymorphism by SSCP analysis}

Migration of the PCR samples as single DNA strands on polyacrylamide gel caused a change in mobility of the isolates of the two pathogens. However, the migration pattern of the single DNA strands provided no informative results until the optimal conditions for separation were determined. Formamide and glycerol in combination had a strong effect on the migration of single DNA strands. The use of only one of these substances always produced less distinct separation patterns. The addition of both substances at low concentrations $(0-7 \%$ formamide, $0-3 \%$ glycerol $)$ had a negative effect on migration; the SSCP patterns were indistinct, with all isolates displaying an identical migration pattern represented by only one band due to a lack of separation or to a minimal and undetectable separation distance between individual strands. High concentrations ( $>20 \%$ formamide, $>7-8 \%$ glycerol), caused a decrease in the separation distance, thus reducing the amount of information supplied by the migration patterns; no difference in mobility of single strands was observed between $S$. cardinale and $S$. cupressi isolates at these concentrations. Higher concentrations failed to distinguish between the species, as no variation in migration was detected. Furthermore, inadequate concentrations of glycerol and formamide 
changed not only the separation distance between strands, but also the separation patterns between isolates, reducing information from the SSCP analysis. The best results were obtained with the addition of $10 \%$ formamide and 5\% glycerol. These concentrations gave a clear separation between strands without affecting the separation pattern of the species. Under room temperature conditions $\left(20-22^{\circ} \mathrm{C}\right)$ the SSCP pattern for all strains was identical, showing two closely migrating bands. The use of lower running temperatures did not improve migration of single nucleic acid fragments in the gels until temperatures of approximately $5-8^{\circ} \mathrm{C}$ were reached. Optimal separation of individual strands, with the clearest and most distinct mobility shifts, was obtained with a gel matrix containing $7-10 \%$ formamide and $3-5 \%$ glycerol under optimized running parameters, which for this DNA fragment were found to be $30-40 \mathrm{~V}$ at $4-5^{\circ} \mathrm{C}$ for $4-8 \mathrm{~h}$. Under these conditions the isolates of $S$. cardinale and $S$. cupressi differed markedly in migration pattern. All $S$. cardinale isolates had a unique migration pattern consisting of two well separated single strands, while the $S$. cupressi isolates comigrated to produce two less separated strands (Fig. 3). No difference in mobility between isolates of $S$. cardinale from the different countries was observed, indicating a substantial sequence homology in the populations of this mitosporic fungus. Variation in electrophoretic conditions did not substantially alter the migration pattern of isolates of the two pathogens. Electrophoresis for $8 \mathrm{~h}$ at $40 \mathrm{~V}$ or overnight running at $20 \mathrm{~V}$ did not cause a detectable increase or decrease in the separation distance between strands.

\section{Discussion}

SSCP is a mutation detection method based on the ability to detect sequence variation in short PCRamplified DNA fragments through the conformation that such fragments assume under electrophoresis as single-stranded molecules in nondenaturing polyacrylamide gels. Under these conditions, the single strands fold back on themselves in a sequence-dependent manner. One or a few nucleotide differences among the scanned DNA segments may cause subtle changes in conformation and thus different degrees of mobility in the gel, allowing their differentiation. Application of this technique to a $340 \mathrm{bp}$ fragment from the rDNA ITS2 region was shown to be an efficient method for differentiating between $S$. cardinale and S. cupressi, the two major fungi associated with cypress canker diseases.

The relatedness of Seiridium species pathogenic on cypress has already been investigated at a molecular level (Viljoen et al., 1993). In a study conducted with 12 Seiridium isolates and based on sequence comparison of a small fragment from the ITS1 region, the amount of variation found did not permit differentiation of isolates, and led these authors to conclude that cypress canker is caused by a single species of Seiridium with

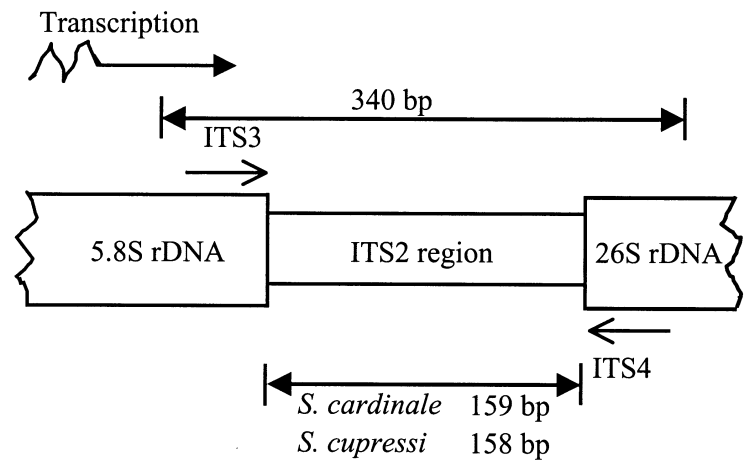

Figure 1 Schematic representation of the $3^{\prime}$ end of the $5 \cdot 8 \mathrm{~S}$ coding region, internal transcribed spacer (ITS2), and $5^{\prime}$ end of the $26 \mathrm{~S}$ subunit. The two primers ITS3-4 produced a fragment of approximately $340 \mathrm{bp}$ in Seiridium isolates. The amplified ITS2 region showed interspecific size polymorphism (distances are given in base pairs).

extensive variation in morphological features. However, there is reason to suspect that the limited number of isolates examined, the unsatisfactory documentation of distinctive characteristics, and the lack or poor quality of type material in at least some cases led to a questionable specific attribution of the isolates. As a consequence, the data presented appear to be insufficient to infer identity at the species level. In reality, the fungi that cause cypress canker are distinct, genuine biological entities and can be recognized by a number of morphological, cultural, physiological and pathogenic characteristics (Graniti, 1998). The present study confirms separation of these taxa.

SSCP analysis is being increasingly adopted in various fields of applied biology. Attempts to transfer this methodology to forest pathology have already given good results, discriminating among intersterility groups of the root-rot pathogen of conifers Heterobasidion annosum, and allowing accurate differentiation of the heteroecious pine rust fungus Cronartium flaccidum from the related, autoecious rust Peridermium pini (Kasuga \& Mitchelson, 1994; Moricca \& Ragazzi, 1998).

The SSCP technique was found to be more effective and sensitive than restriction analysis of amplified ribosomal DNA. With the RFLP technique, all isolates tested shared identical restriction sites and fragment lengths. The monomorphic profiles obtained were due to the conservation of many restriction sites, a result that indicates a high degree of relatedness between these fungi. Such closeness was confirmed by DNA sequencing of representative isolates, with only three base differences found in the fragment analysed between the two species.

A comparison of the two methods was undertaken because most laboratories do not have equipment for SSCP analysis, but RFLP is more commonly available. However, with growing demands for high resolution and accuracy, in conjunction with the need for cost and time saving, the rationalization of genetic analysis methodologies is desirable. 
ITS 2 Region

$\begin{array}{lllll}10 & 20 & 30 & 40 & 50\end{array}$

S. ca-Fclus69

TACAACCCTT AAGCCTAGCT TAGTATTGGG AGTCTACTGT ATTGTAGTTC

S. Cu-Kos

TACA

AluI DdeI HinfI

S. ca-Fclus69

51

60

70

80

90

100

S. cu-Kos

CTCAAATCCA ACGGCGGATC TGTGGTATCC TCTGAGCGTA GTAAATTTTT CTCAAATCCA ACGGCGGATC TGTGGTATCC TCTCAAGGTA GTAAATTTTT

Sau3AI

DdeI

S. ca-Fclus69
S. cu-Kos

\begin{abstract}
101
110

120

130

140

150

ATCTCGCTTT TGTCAGGTGC TGCAGCTCCC AGCCGCTAAA CCCCCAAATT

ATCTCGCTTT TGTCAGGTGC TGCAGCTCCC AGCCGCTAAA CCCCCAAATT
\end{abstract}

\section{AluI}

\section{S. Ca-Fclus69 \\ S. Cu-Kos}

\section{1 160 \\ TTTTAATGG \\ TTTTAATTG}

Figure 2 Aligned nucleotide sequences of the antisense strand of the ribosomal DNA internal transcribed spacer 2 (ITS2) region of S. cardinale and S. cupressi, with restriction site map for four enzymes. Shaded portions indicate positions in which variant nucleotides occurred, with a dash indicating a gap.

The rationale for applying SSCP to explore isolates of the two pathogens resides in the current state of knowledge on the origin and reproductive biology of these related fungi and their genetic diversity. Both introduced species ( $S$. cardinale from western USA and $S$. cupressi from Kenya) lack sexual reproduction (completely unknown for $S$. cardinale, while the teleomorph of $S$. cupressi, Lepteutypa cupressi, is exceptionally rare). In the absence of sexual reproduction, genomes were suspected to be homogeneous, with a limited range of variation at the intraspecific level.

Although the PCR-SSCP technique distinguished the two species, it was necessary to optimize the experimental conditions: type of gel matrix (acrylamide : bisacrylamide ratio); electrophoretic conditions (especially running temperature, running time, formamide and glycerol concentrations); size of amplicons to be scanned; dimensions of the gel; overloading of the gel, etc. The electrophoretic mobility of single DNA strands was found to be strongly dependent on the environmental conditions. When uniform conditions were applied, informative and reproducible migration patterns were obtained. All isolates within each species comigrated to give the same separation patterns. These identical migration patterns reflected the sequence homology existing at the intraspecific level, as seen by sequence inspection. A marked difference was observed between the electrophoretic mobility of isolates identified as $S$. cardinale and those identified as S. cupressi. Because electrophoretic behaviour directly reflects differences in nucleotide composition of the fragments screened, the assay provided conclusive evidence of polymorphism among the taxonomic entities investigated; a single-base deletion and two base substitutions in the ITS2 region

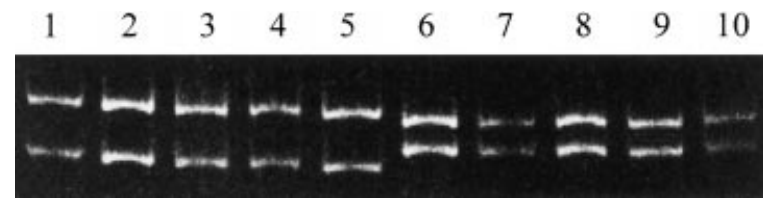

Figure 3 PAGE-SSCP patterns of PCR-generated ITS2 products of the S. cardinale isolates Fsc2, ATCC 38654, 10S, Scj and Mouz (lanes 1-5) and the $S$. cupressi isolates ATCC 48158, CBS227.55, CBS320.51, CBS225.55 and Bsc55 (lanes 6-10) under optimized running conditions: migration at $4^{\circ} \mathrm{C}$ for $5 \mathrm{~h}$ at $40 \mathrm{~V}$ in a gel matrix containing $10 \%$ formamide and $5 \%$ glycerol. All S. cardinale isolates had a unique profile of two well separated, comigrating single DNA strands and were clearly differentiated from the $S$. cupressi isolates which displayed an identical profile of two less-separated, comigrating single DNA strands. 
were sufficient to alter strand mobility in the polyacrylamide gel, thus differentiating $S$. cardinale from S. cupressi.

The development of an assay enabling rapid differentiation of the two microorganisms is important because both pathogens are well adapted to the environmental conditions predominant in the Mediterranean basin, and a combination of concurrent factors could transform the diseases caused by these fungi into severe and widespread epidemics in this area. These factors include: (i) favourable climatic conditions; (ii) extensive presence of susceptible hosts; (iii) the density and contiguity of cypress stands and plantations; (iv) the presence of a number of vectors such as insects (corkborers, Phloeosinus spp. and a seed-bug, Orsillus maculatus) and birds; (v) frost and wind damage which cause small bark lesions through which infections may penetrate (Panconesi, 1990); and (vi) atmospheric conditions that allow maturation and discharge of conidia repeatedly throughout the year.

\section{Acknowledgements}

Research supported by National Research Council of Italy. Special Project 'Diagnosi precoce di malattie nelle piante di interesse agrario e forestale', paper No. 3. We are grateful to all colleagues listed in Table 1 for their generous gift of Seiridium cultures. The technical assistance of Mr G. Torraca and Mr V. Di Lonardo is appreciated. The $S$. cardinale and $S$. cupressi sequences reported here are deposited in GenBank, accession numbers AF262560 and AF262561, respectively.

\section{References}

Bassam BJ, Caetano-Anolles G, Gresshoff PM, 1991. Fast and sensitive silver staining of DNA in polyacrylamide gels. Analytical Biochemistry 196, 80-3.

Barthelet J, Vinot M, 1944. Notes sur les maladies des cultures méridionales. Annals of Epiphytology 10, 11-3.

Boesewinkel HJ, 1983. New records of three fungi causing canker in New Zealand, Seiridium cupressi (Guba) comb. nov. and S. cardinale on Cupressocyparis and S. unicorne on Cryptomeria and Cupressus. Transactions of the British Mycological Society 80, 544-7.

Chou CK, 1989. Morphological and cultural variation of Seiridium spp. from cankered Cupressaceae hosts in New Zealand. European Journal of Forest Pathology 19, 435-45.

Graniti A, 1986. Seiridium cardinale and other cypress cankers. OEPP/EPPO Bulletin 16, 479-86.

Graniti A, 1993. Seiridium blight of cypress - another ecological disaster? Plant Disease 77, 544.

Graniti A, 1998. Cypress canker: a pandemic in progress. Annual Review of Phytopathology 36, 91-114.

Grasso V, 1951. Un nuovo agente patogeno del Cupressus macrocarpa Hartw. in Italia. L'Italia Forestale e Montana 6, $62-5$.

Kasuga T, Mitchelson K, 1994. The development of rapid identification of Heterobasidion annosum intersterility groups by ribosomal RNA gene polymorphism and by minisatellite allele polymorphism. In: Schots A, Dewey FM, Oliver R, eds. Modern Assays for Plant Pathogenic Fungi: Identification, Detection and Quantification. Wallingford, UK: CAB International, 117-26.

Lee SB, Taylor JW, 1990. Isolation of DNA from fungal mycelia and single spores. In: Innes MA, Gelfand DH, Sninski JJ, White TJ, eds. PCR Protocols: A Guide to Methods and Applications. New York: Academic Press, 282-7.

Luisi N, 1990. Ricerche su aspetti biologici ed epidemiologici di Seiridium cardinale nell'Italia meridionale, con indicazioni di lotta. Annali dell'Accademia Italiana Di Scienze Forestali 38, 286-331.

Moricca S, Ragazzi A, 1998. Use of RFLP and SSCP analysis to differentiate the pine rusts Cronartium flaccidum and Peridermium pini. Mycological Research 102, 666-70.

Nag Raj TR, 1994. Coelomycetous Anamorphs with Appendage-Bearing Conidia. Waterloo, Ontario, Canada: Mycologue Publications.

Nattrass RM, 1945. A canker of Cupressus macrocarpa in Kenya caused by Monochaetia unicornis. East African Agricultural Journal 11, 82.

Nattrass RM, Booth C, Sutton BC, 1963. Rhynchosphaeria cupressi sp. nov., the causal organism of Cupressus canker in Kenya. Transactions of the British Mycological Society 46, $102-6$.

Norkrans B, 1963. Influence of some cultural conditions on fungal cellulose production. Physiologia Plantarum 16, 11-9.

Panconesi A, 1990. Pathological disorders in the Mediterranean basin. In: Ponchet J, ed. Progress in EEC Research on Cypress Disease. Report Eur 12493. Luxembourg: EC, 112-26.

Panconesi A, Raddi P, 1990. Una realtà presente per il futuro del cipresso. Selezionati cloni resistenti al cancro. Cellulosa e Carta 41, 29-31.

Panconesi A, Raddi P, 1991. Agrimed n.1 and Bolgheri: due nuove selezioni resistenti al cancro del cipresso. Cellulosa $e$ Carta 42, 47-52.

Ponchet J, Andreoli C, 1990. Compartmentalization and reactions in the host. In: Ponchet J, ed. Progress in EEC Research on Cypress Disease. Report Eur 12493. Luxembourg: EC, 97-111.

Raddi P, Panconesi A, Sumer S, 1987. Il cipresso in Turchia: considerazioni di un viaggio di studi. Monti e Boschi 1, 67-72.

Raddi P, Panconesi A, Xenopoulos S, Ferrandes P, Andreoli C, 1990. Genetic improvement for resistance to canker disease. In: Ponchet J, ed. Progress in EEC Research on Cypress Disease. Report Eur 12493. Luxembourg: EC, 112-26.

Raeder U, Broda P, 1985. Rapid preparation of DNA from filamentous fungi. Letters in Applied Microbiology 1, 1720.

Sanger F, Micklen S, Coulson AR, 1977. DNA sequencing with chain-terminating inhibitors. Proceedings of the National Academy of Science, USA 74, 5463-7.

Solel Z, Messinger R, Golan Y, Madar Z, 1983. Coryneum canker of cypress in Israel. Plant Disease 67, 550-1.

Sparapano L, Graniti A, Evidente A, 1994. Recent progress in the research on toxins produced by species of Seiridium associated with cypress canker diseases. In: Capretti P, Heiniger U, Stephan R, eds. Shoot and Foliage Diseases in 
Forest Trees. Proceedings of IUFRO Working Parties S2.06.02 and S2.06.04, Vallombrosa, Firenze, Italy. Tipografia Bertelli. 126-31.

Sutton BC, 1980. The Coelomycetes. Kew, UK: Commonwealth Mycological Institute.

Swart HJ, 1973. The fungus causing cypress canker. Transactions of the British Mycological Society 61, 71-82.

Viljoen CD, Wingfield BD, Wingfield MJ, 1993. Comparison of Seiridium isolates associated with cypress canker using sequence data. Experimental Mycology 17, 323-8.

Wagener WW, 1939. The canker of Cupressus induced by Coryneum cardinale n. sp. Journal of Agricultural Research $58,1-46$.
White TJ, Bruns T, Lee S, Taylor J, 1990. Amplification and direct sequencing of fungal ribosomal RNA genes for phylogenetics. In: Innes MA, Gelfand DH, Sninski JJ, White TJ, eds. PCR Protocols: A Guide to Methods and Applications. New York, USA: Academic Press, 315-22.

Wimbush SH, 1944. Canker of Monterey cypress in Kenya. Empire Forestry Journal 23, 74.

Xenopoulos S, 1987. A new pathogen for Greece causing the cypress canker disease. Dasiki Erevna 2, 85-94.

Xenopoulos SG, 1991. Pathogenic variability of various isolates of Seiridium cardinale, S. cupressi and S. unicorne inoculated on selected Cupressus clones and seedlings. European Journal of Forest Pathology 21, 129-35. 